\title{
STUDIES ON THE REACTIONS OF SOYBEAN CULTIVARS TO THE ROOT-KNOT NEMATODE, Meloidogyne javanica INFECTIONS AND THEIR NODULATION ABILITY IN THE SOIL
}

\author{
R. O. Ogbuji and T. A. Awolola \\ Department of Crop Science \\ University of Nigeria, Nsukka \\ Nigeria.
}

\begin{abstract}
Twenty-three cultivars of soybean (Glycine max (L.)) consisting of five early maturing, nine each of medium and late maturing types were rated in replicated trials in the field to the root-knot nematode, Meloidogyne javanica. All early maturing type, 49-9, Type Green, Kongo Yellow, AGS 66 and Roanoke were highly resistant to the nematode. Three medium maturing types highly resistant were TGX 536-02D, TGX 539-5E and TGX 297-10F. Seven late maturing type found highly resistant were M312, TGX 306-036C, TGX 814-45E, TGX 814-36E, TGX 855-6ID, Malayan and TGX 814-27D. Sixteen cultivars were rated good to excellent nodulators with rhizobium bacteria, of which only one, 49-9 was of the early maturing type; Samsoy 1, TGX 536-02D, TGX 297$10 F$ and TGX 814-54D were of the medium maturing type; the seven late maturing type were M312, TGX 293-63E, TGX 814-45E, TGX 814-36E, TGX 855-61D. Malayan and TGX 814-27D.
\end{abstract}

\section{INTRODUCTION}

Grain legumes and oil seed crops have been helpful in alleviating the protein crisis of the developing nations. One of the most important grain legumes is the soybean (Glycine max L.). With the exception of the South American lupine, soybean seeds have the largest protein content of all cultivated legumes (Aykrod \& Doughty, 1964; Cobley, 1976). Apart from being good and cheap protein source (Leng, 1968), soybeans have other beneficial effects on agriculture. They are used as forage crops. They are symbionts of bacteria that form root nodules (Cobley, 1976). Consequently, they increase the level of soil nitrogen, thus increase yields (Ogbuji, 1981). Such serious losses in soybeans result in reduced protein intake by most people in the tropics who depend on legumes as a cheap source of getting essential amino acids needed for good body health. In this study the responses of twenty-three cultivars of soybean to Meloidogyne javanica in the field as well as their ability to nodulate in the soil were investigated.

\section{MATERIALS AND METHOD}

The University of Nigeria farm on which this experiment was conducted was first planted with maize in 1984. In August 1985 the soil was sampled for the presence of nematodes. The land was ploughed and harrowed July 1986 for this soybean experiment. The textural class of the Nsukka ultisol is loamy sand with $\mathrm{pH}\left(\mathrm{H}_{2} \mathrm{O}\right)$ of 5.81. NPK (15-15-15) fertilizer was applied at the rate of $150 \mathrm{~kg} / \mathrm{ha}$. The fertilizer was worked in by a second harrowing. The land was blocked into eight. Three blocks each were assigned to nine medium, and nine late maturing soybean cultivars, while two blocks were assigned to the early type. Each block had nine plots, except the second block of the early type which had six plots only. Plot sizes were $6 \mathrm{~m} \times 3 \mathrm{~m}$ for medium and early maturing cultivars, $6 \mathrm{~m} \mathrm{x}$ $4.5 \mathrm{~m}$ for the late maturing cultivars, while two blocks were assigned to the early type. Seeds were sown by drilling on July 12, 1986. Each soybean cultivar was grown in three plots. Each plot had six rows. each $6 \mathrm{~m}$ long. Intra- 
Table 1: Mean root-knot and nodulation indices of soybean cultivars in the field.

\begin{tabular}{llll}
\hline Maturing type & Cultivar & Root-knot index & Nodulation index \\
\hline \multirow{2}{*}{ EARLY } & & $(0-4)^{*}$ & $(1-5)^{*}$ \\
& $49-9$ & 0.00 & 5.00 \\
& Type Green & 0.00 & 1.00 \\
& Kongo Yellow & 0.00 & 1.00 \\
MEDIUM & AGS 66 & 0.00 & 1.00 \\
& Roanoke & 0.00 & 1.67 \\
& Samsoy 1 & 3.33 & 3.67 \\
& TGX 536-02D & 0.00 & 3.67 \\
& TGX 297-6F & 2.67 & 3.33 \\
& TGX 814-49E & 3.67 & 5.00 \\
& TGX 813-6D & 2.67 & 3.00 \\
& TGX 814-26D & 3.00 & 4.67 \\
& TGX 539-5E & 0.00 & 1.00 \\
LATE & TGX 297-10F & 0.33 & 5.00 \\
& TGX 814-54D & 4.00 & 4.00 \\
& M312 & 0.00 & 3.67 \\
F-LSD 0.05 & TGX 293-63E & 2.67 & 3.33 \\
& TGX 306-036C & 0.67 & 1.67 \\
\hline
\end{tabular}

* Numbers are means of three replicates, on plot basis

row spacing was $0.5 \mathrm{~m}$ for the early and medium maturing types; $0.7 \mathrm{~m}$ for the late types.

The experiment was a randomized block design (RCBD) with three replications, Vetox 85 was applied against insect pests. It was mixed in water at a concentration of $23 \mathrm{~g} / 10$ litres of water.

Soybean roots were sampled when the plants were three months old. Sampling involved uprooting carefully ten plants per plot randomly and washing roots in tap water to remove adhering soil. In the laboratory, the roots were assessed for the amount of galling caused by the root-knot nematode, and for the amount of nodulation caused by rhizobium bacteria. Ten severely galled roots were selected randomly and processed in the laboratory to identify the species of the rootknot nematode present, using the method of Taylor et al (1955).

Scoring indices used for root-knot infection were those of Ogbuji (1978):

$\begin{array}{rll}0 \quad & \text { no infection (no galls); } \\ 1 & = & \text { rare infection }(1-3 \\ & \text { galls); }\end{array}$

2

$\begin{array}{ll}3 \quad=\quad \begin{array}{l}\text { moderate infection } \\ \end{array} & (11-30 \text { galls }) ; \\ 4 \quad & \text { severe infection }\end{array}$

The following scoring indices used for nodulation were sourced from IITA Annual Report (1981):

$\begin{array}{lll}1 & = & \text { no nodulation } \\ 2 & = & \text { few nodules }(1-4 \\ & & \text { nodules }) \\ 3 & & \text { good nodulation } \\ & (5-10 \text { nodules }) \\ 4 & & \text { very good nodulation } \\ & (11-20 \text { nodules }) \\ 5 & =x c e l l e n t \text { nodulation } \\ & & (>20 \text { nodules })\end{array}$

\section{RESULTS AND DISCUSSION}

Identification of the root-knot nematode species

The species of the root-knot nematode 
attacking the soybean roots was Meloidogyne javanica. The tail (perineal) patterns showed low, regular arch striations; conspicuous lateral lines and absence of whorls. These are features common to $M$. javanica.

\section{Root galling responses}

Susceptibility of the soybean cultivars as indicated by their galling responses are shown in Table 1. They varied from zero infection (root index $=0$ ), to severe infection (root index $=4$ ). Zero galling responses cut across the three maturing types. A point of interest. however, was that all the five cultivars of the early maturing types had zero mean galling. of the nine medium maturing cultivars, two had zero mean galling; one had mean root gall index of 1; five were moderately to severely galled. Five cultivars of the late maturing types had mean zero galling; two had mean gall number of 1 . Two cultivars were moderately galled (Table 1). A cultivar with mean gall index $<2$ is regarded as being resistant. Gall indices of 2 and above indicate susceptibility.

The following cultivars appeared immune to $M$. javanica: 49-9, Type Green, Kongo Yellow, AGS 66, Roanoke, TGX 536-02D, TGX 539-5E. Others were M312, TGX 81445E, TGX 814-36E, TGX 855-61D and TGX 814-27D. The following cultivars were highly resistant: TGX 297-10F, TGX 306-036C and Malayan. Susceptible cultivars: Samsoy 1, TGX 297-6F, TGX 814-49E, TGX 813-6D, TGX 814-54D, TGX 293-63E and TGX 725$011 \mathrm{D}$ (Table 1).

\section{Nodulation ability}

The ability of the soybean cultivars to nodulate differed within and between maturing types. The responses ranged form very poor to excellent nodulation (Table 1). It was noted that of the five early maturing cultivars, only one nodulated excellently. Three of the remaining four had zero mean nodulation. Eight of the nine medium maturing type had good to excellent nodulation. Similarly, seven of the nine late mafuring type were good or very good nodulators. The excellent nodulators were: 49-9 (early), TGX 814-49E and TGX 297-10F (medium).

Zero to very poor nodulators: Type Green, Kongo Yellow, AGS 66, Roanoke (early); TGX 539-5E (medium), TGX 306-036C and TGX 725-011D (late). All the remaining cultivars (medium and late) were either good or very good nodulators (Table 1).

Data were not taken on the vegetative growths of the different maturing types. However, the early maturing types were shorter than the medium or late maturing types. At the time of root examination, pods of the early maturing plants were fully ready for harvest; leaves of the medium types were turning yellow while those of the late types were still green.

Results of this field experiment showed that some soybean cultivars were not attacked or were slightly attacked by $M$. javanica. They were therefore regarded as resistant to the nematode. Some cultivars were moderately susceptible and others highly susceptible. Varying plant responses to disease infection have genetic basis, plus the modifying environment. It is possible that the fifteen soybean cultivars that appeared resistant to Nsukka population of $M$. javanica could respond similarly in other locations if the environmental conditions and race identity of the nematode are the same. It is also possible that given these same conditions, results could still differ, even if slightly because nematode distributions in the field are rarely even. Under field conditions, plant resistance to infection may derive simply from disease escape.

Nodulation responses by legumes is still a matter which has to be better understood through research. The nodulating bacteria in the genus Rhizobium interact intimately with legume plants before nodulation actually takes place (Russel, 1973). In this experiment, excellent nodulators included cultivars like 49 . 9, TGX 814-49E, TGX 297-10F, Samsoy 1 and Malayan. Legumes that nodulate well are beneficial by way of soil nitrogen fixation (Trager, 1970). However, some of the good to excellent soybean cultivars were also highly susceptible to $M$. javanica (Table 1.) Root galls and nodules were present on the same 
roots. By this, both Meloidogyne spp and Rhizobium spp can co-exist in a root system. However, it has also been shown that concomittant inoculation of cowpea seedlings with a Meloidogyne sp and cowpea Rhizobium resulted in drastic reduction of root galls and nodules in the root system (Ogbuji, 1976; Ogbuji \& Inyang, 1981). Some other nematodes do provide infection courts to invading bacteria (Pitcher, 1963). A way to protect legume cultivars which nodulate profusely but are susceptible to Meloidogyne spp is to fumigate nematode infested soils before such legumes are sown. Alternatively, direct sowing of a highly nodulating cultivar, highly resistant to a Meloidogyne sp is ideal. In this experiment, the soybean cultivar 49-9 provides an example.

\section{References}

Aykroyd, W. R. and J. Doughty (1976). Legumes in human nutrition. FAO Nutritional

Studies. Rome: FAO.

Cobley, S. L. (1976). An Introduction to the Botany of Tropical Crops. Longman, London.

IITA (1981). International Institute of Tropical Agriculture Annual Report. Ibadan, Nigeria. pp 178.

Leng, E. R. (1968). Soybean. Potential for extension into areas of protein shortage. Econ. Bot. 22: 37-41.

Ogbuji, R. O. (1976). Responses of cowpea (Vigna unguiculata) to inoculation with root-knot nematode (Meloidogyne incognita) and cowpea Rhizobium. Niger. Agric. J. 13: 125-131.

Ogbuji, R. O. (1981). Infectivity of three Meloidogyne spp on soybeans in Nigeria. Trop. Landwrit. 62: 149-152.

Ogbuji, R. O. and U. E. Inyang (1981). Interaction of the Nematode, Meloidogyne incognita and Rhizobium as co-inhabitants in two legume plants. Niger. $J$. Pl.

Prot. 5: 53-55.
Pitcher, R. S. (1963). Role of plant parasitic nematodes in bacterial diseases. Phytopath. 53: 35-39.

Russel, E. W. (1973). Soil Conditions and Plant Growth. Longman, N. Y.

Taylor, A. L., V. H. Dropkin and G. C. Martin (1955). Perineal patterns of root-knot nematodes. Phytopath. 45: 26-34.

Trager, W. (1970). Symbiosis. Van Nostrand Reinhold Coy. N. Y. 